\title{
DIAGNOSES OF POTENTIAL EROSION AREAS AND LAND USE CONFLICTS IN THE ARAPUTANGA MUNICIPALITY, MATO GROSSO STATE (MT), BRAZIL
}

\author{
Camila Calazans da Silva LUZ1 \\ Cleber Aparecido de BARROS 1 \\ Sandra Mara Alves da Silva NEVES2 \\ Ronaldo José NEVES 2 \\ Maria Cândida Moitinho NUNES 3
}

\begin{abstract}
The objective of this study was to diagnose the potential degradation areas due to water erosion and the conflicts derived from land use in the Araputanga municipality / Mato Grosso State. A geomorphologic and pedologic compartmentalization was generated from the superposition of soil and geomorphology maps; the erodibility by the association of the soils map of the erodibility information; the susceptibility to water erosion from the combination of the erodibility maps and the topographic factor. The vegetation cover and land use map were drawn from the Landsat 8 images of 2016. The current potential for water erosion was generated from the combination of maps on susceptibility to erosion with land cover/land use. For the assessment of conflicts, maps of current potential for water erosion and land use capacity were used. In Araputanga municipality, the Luvisols cover $62.93 \%$. A high erodibility predominates in $73.09 \%$; human activities occupy $64.98 \%$. There is an average potential to water erosion in $86.31 \%$ and an average for land use conflict in $40.40 \%$. The high erodibilitydue to the physical and chemical characteristics of the soil appears in gullies. It is necessary to readjust the land use in order to reduce the environmental problems and to maintain the landscape functions.
\end{abstract}

Key words: Geo-technologies. Erosive processes. GIS. Environmental degradation.

\footnotetext{
1 Universidade do Estado do Mato Grosso UNEMAT/Campus of Tangará da Serra Masterís Graduate Program in Environment and Agriculture Production Systems Rod MT $358 \mathrm{~km} 07$ Box 287 Jardim Aeroporto Tangará da Serra, Mato Grosso. CEP: 78300-000. E-mails: camila_agronomia@hotmail.com; cleberapbarros@hotmail.com

2 Universidade do Estado de Mato Grosso-UNEMAT/Campus Cáceres. Associate professor of the Geography department. Laboratory of Geotechnology. Avenue. Santos Dumont, w/n. Santo Dumont. CEP: 78200-000 Cáceres/MT, Brasil.E-mail-s: ssneves@unemat.br; rjneves@unemat.com

3 Universidade Federal de Pelotas (UFPEL)- Faculdade de Agronomia Eliseu Maciel/FAEM. Professor of Agronomy Course Assistant. Campus w/n, CP 354, CEP: 96010-900, Pelotas/RS. E-mail: nunes.candida@gmail.com
} 


\section{Resumo}

\section{Diagnósticos de áreas potenciais à erosão e conflitos de uso da terra no município matogrossense de Araputanga, Brasil}

O objetivo deste estudo foi diagnosticar as áreas potenciais à degradação por erosão hídrica e os conflitos derivados do uso da terra no município de Araputanga/MT. A compartimentação morfopedológica foi gerada da sobreposição dos mapas de solos e geomorfologia; a erodibilidade pela associação ao mapa de solos das informações de erodibilidade; a susceptibilidade à erosão hídrica da combinação dos mapas de erodibilidade com o de fator topográfico. O mapa de cobertura vegetal e uso da terra elaborado a partir das imagens do Landsat 8 de 2016. O potencial atual à erosão hídrica foi gerado a partir da combinação dos mapas de susceptibilidade à erosão com o de cobertura e uso da terra. Na avaliação dos conflitos foram utilizados os mapas de potencial atual à erosão hídrica e o de capacidade de uso da terra. Em Araputanga os Luvissolos recobrem 62,93\%; Predomina em 73,09\% a erodibilidade alta; As atividades antrópicas ocupam 64,98\%; Ocorre em $86,31 \%$ médio potencial à erosão hídrica e $40,40 \%$ médio conflito de uso. A alta erodibilidade, decorrente das características físicas e químicas do solo, reflete em voçorocas, sendo necessária a readequação do uso das terras para que ocorra a redução dos problemas ambientais e a manutenção das funções dos componentes da paisagem.

Palavras-chave: Geotecnologias. Processos Erosivos. SIG. Degradação Ambiental.

\section{INTRODUCTION}

Agricultural development in Brazil is increasing fast, and one of its characteristics is the massive use of natural resources and the incipience of adequate planning, which together with the edaphic-climatic characteristics promotes soil erosion losses.

According to Oliveira et al. (2010, p.141), millions of tons from agricultural soil due to erosion are lost every year throughout Brazil. This situation persists, since losses continue to be high due to missing appropriate management techniques to the soil, causing environmental, financial and social damages.

The main human activities contributing to the acceleration of landscape degradation components (geomorphology, pedology, hydrography, etc.) are agriculture, mining, excavation and road opening (INBAR et al., 1998, p.29).

According to Mafra (1997, p.113), the study of erosion processes and detection of most susceptible areas should be done together with land planning, aiming to regulate human action on fragile sites, with minimum incidence of use to avoid damages to economic activities and the environment.

So it is necessary not only to indicate the environmental problems caused by society and the way to recover them, but also to analyze the degree of fragility from the different environments to the interferences, aiming to minimize the environmental risks. Planning is based on a holistic reading of the environment, considering the process of occupation, development and appropriation of the territory and its resources, always focusing on the conservation of its structure, fauna and flora (ROSS, 1990; LIMA; MARTINELLI, 2008, p.01).

In this sense, one of the most efficient ways to provide subsidies to the selection of priority areas from the point of view of soil conservation and recovery is the use of potential to laminar erosion maps, which can efficiently show the expectation of loss from soils under land occupation systems and the basic zoning with restricted areas for occupation (FROTA; NAPPO, 2012, p.1480; ARAGÃO et al., 2011, p.732). 
The land incorporation process in the Araputanga municipality for the development of farming activities implied in changes of the natural dynamics and degradation of landscape components. Therefore, this study aims to diagnose potential degradation by water erosion and the conflicts derived from the land use in the Araputanga municipality using geo-technologies, to contribute with subsidies for the land use adequacy and municipal planning.

\section{MATERIAL AND METHODS}

\section{Area under study}

The Araputanga municipality, with an area of $1,600,240 \mathrm{~km}^{2}$ (BRASIL, 2017), is part of the SW Mato Grosso Planning Region (MATO GROSSO, 2012) and it is $350 \mathrm{~km}$ from the capital, Cuiabá (Figure 1).

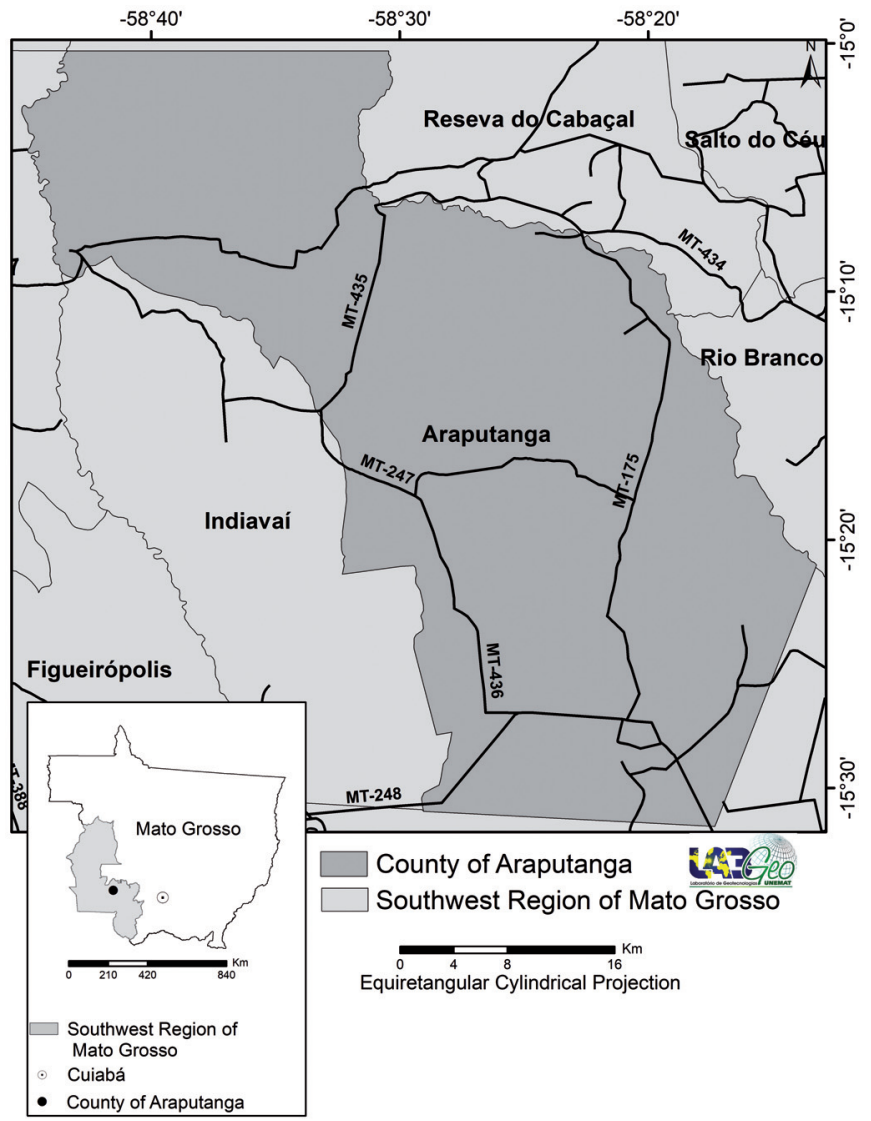

Figura 1 - Araputanga municipality in the regional and municipal contexts Source: Labgeo UNEMAT, 2017. 
It has a population of 15,342 inhabitants (BRASIL, 2017), from which $80.40 \%$ live in the urban area and $19.60 \%$ in the rural area. It has a Human Development Index (HDI) of 0.725 , equal to the State average, which is 0.725 (UNDP, 2010). The climate in the region is the Moist Mega-thermal Tropical of the Lower Jauru-Rio Branco Plateaus and Depressions, with annual average temperatures above $25^{\circ} \mathrm{C}$ and rainfall totals between 1400 and $1600 \mathrm{~mm}$. Its main characteristics are two, well defined as dry and rainy seasons Water deficits become moderate to severe, from 200 to 250 $\mathrm{mm}$, and there is also a decrease in water surpluses, ranging from 200 to $600 \mathrm{~mm}$ (TARIFA, 2011, p. 84).

\section{Methodological procedures}

The cartographic bases of Soils and Geomorphology maps were obtained, at scale 1: 250,000, at the State Secretary for Planning and General Coordination of Mato Grosso State - SEPLAN / MT. These were later compiled, matched and organized into the Geographic Database in ArcGIS, version 10.5 (ESRI, 2017).

For the Vegetaion Cover and Land Use maps, Landsat 8 images from 2016, Orbit 228, Points 70 and 71 were acquired, with spatial resolution of 30 meters. The following procedures were performed: cutting, segmentation, supervised classification with Spring software from the National Institute for Space Research - INPE (CÂMARA et al., 1996) version 5.2.6 and post classification with ArcGis. Clipping was made using the digital cartographic base of the municipality as a mask.

The segmentation was made using the region growth method; similarity thresholds were 100 and area 100. According to Nascimento et al. (1998, p.983), similarity refers to the maximum Euclidean distance between the spectral centers of two regions and the area is the minimum pixel size of a region to be delimited. Eight classes were defined in the classification made, based on literature research at the Project for Conservation and Sustainable Use of Brazilian Biological Diversity - PROBIO I (BRASIL, 2007a) and the Technical Manual for Vegetation and Land Use (IBGE, 2012). The classifier used for this procedure was Bhattacharya, with an acceptance threshold of $99.99 \%$. The classification obtained was exported in Shape file format. The postclassification was carried out in ArcGIS, using the information obtained during field survey carried out in February and July 2016.

The geomorphologic and pedologic compartmentalization were performed with the association of Geomorphology and Soils maps in ArcGis, (MATO GROSSO, 2007), using the Intersect tool.

The erodibility map was generated by the insertion in the Soils map, which nomenclature was updated according to Embrapa (2006, p.339), considering class information and indexes related to erodibility, suggested by Salomão (2010, p. 239) and Carvalho (2008, p.220).

The Topographic Factor Map (LS) corresponds to the map of iso-declivities from Salomão (2010) and was obtained from a Digital Elevation Model (DEM), generated from the interferometry radar (SRTM - Shuttle Radar Topography Mission), with spatial resolution of $30 \times 30 \mathrm{~m}$, available free of charge from the United States Geological Survey (USGS). The digital processing of the scenes included: mosaic generation, verification of negative altitude values, as well as non-existent altitude values and projection conversion. After its reclassification and combination, a map of homogeneous ramps was generated. From this map, values of mean ramp slope and ramp height were obtained, according to the methodology proposed by Fornelos and Neves (2007, p. 186). 
The relief was classified according to BRASIL (2007b, p.265) considering the following categories: Slope 0 to $3 \%$ - flat relief; from 3.1 to $8 \%$ - soft rolling relief; 8.1 to $20 \%$ - rolling relief; from 20.1 to $45 \%$ - strong rolling relief; 45.1 to $75 \%$ - mountainous relief; and $>75 \%$ - steep relief.

The preliminary map of susceptibility to laminar water erosion was generated from the combination of ArcGis with the Combine function, Erodibility map and Topographic factor (LS). The definitions of erosion susceptibility classes, based on the percentage of slope, followed IPT classification (1990, p.25): I) Extremely susceptible; II) Very susceptible; III) Moderately susceptible; IV) Little susceptible and V) Little to not Susceptible. After the reclassification, the final version from the Map on Susceptibility to Erosion was generated.

In order to obtain a map of the current potential for water erosion, the map of susceptibility to water erosion was made compatible with the current land use map. The classification of the current potential for erosion was done as proposed by Salomão (2010, p.243): Class I: high potential - current soil use incompatible with susceptibility to laminar water erosion; Class II: medium potential - current soil use incompatible with susceptibility to laminar water erosion, possibly controlled with adequate conservation practices and Class III: low potential - current soil use compatible with susceptibility to laminar water erosion.

For the evaluation of conflicts, the information derived from maps of current potential to water erosion and land use classification (LEPSCH, 1991, p.50) was analyzed. The classification of the conflict, as well as the relationship between susceptibility to water erosion and land use capacity were made using the methodology proposed by Hermuche et al. (2009, p.118), according to the table below:

\section{Table 1 - Relation between susceptibility to linear erosion and land use capacity}

\begin{tabular}{ll}
$\begin{array}{c}\text { Susceptibility to linear erosion } \\
\text { (Salomão, 1999) }\end{array}$ & $\begin{array}{c}\text { Land use capacity } \\
\text { (Lepsch, 1991) }\end{array}$ \\
\hline Class I - Extremely Susceptible & Class VII e VIII \\
Class II - Very Susceptible & Class VI \\
Class III - Moderately Susceptible & Class IV \\
Class IV - Susceptible & Class III \\
Class V - Non-susceptible & Classes I, II e V \\
\hline
\end{tabular}

The generated files were corrected by information obtained in the field and after that, making use of the ArcGIS version 10.5., the layouts and the quantifications which subsidized the analysis were elaborated

\section{RESULTS AND DISCUSSION}

Three categories of vegetation cover and land use were identified (Figures 2 and 3), with eight thematic classes, three of which refering to natural vegetation, four to human use and one to water bodies (Table 2 ). 


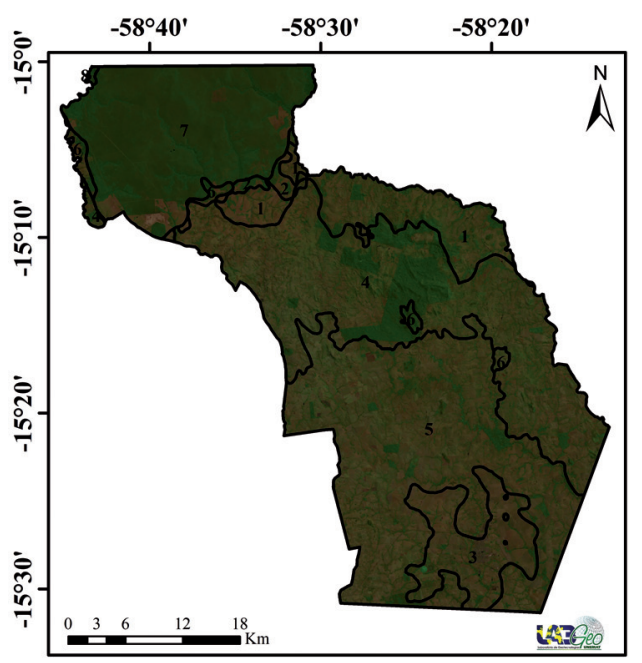

Vegetation Human Use

Figure 2 - Image Picture of the municipality of Araputanga / MT

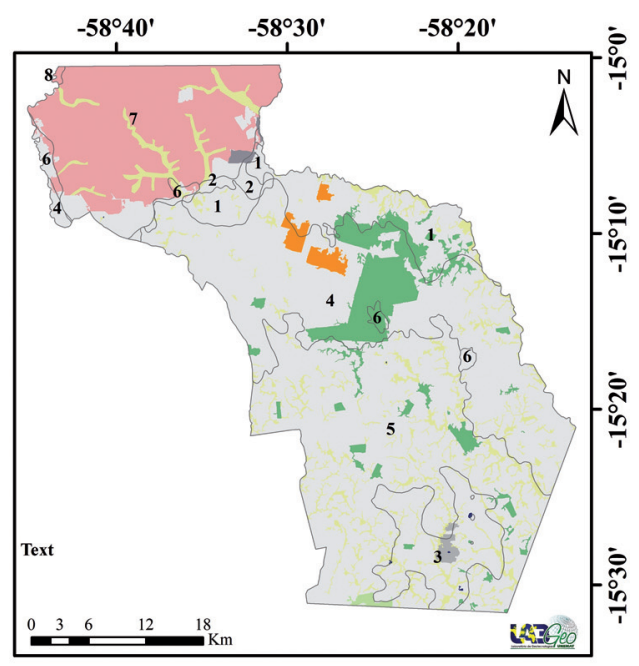

Agro-Livestock + Secondary Vegetation

Alluvial Semi-deciduous Seasonal Forest

Sub-montane Semi-deciduous Seasonal Forest

Sub-montane Semi-deciduous Seasonal Forest

+ Secondary Vegetation

Urban Influence

Water mass

Livestock

Livestock + Secondary Vegetation

Forest Savanna + Park Savanna

Savanna/ Seasonal Forest

Figure 3 - Land use/land cover of geomorphologic-pedologic compartments in the Araputanga/ MT municipality

Table 2 - Description of vegetation cover and land use of Araputanga/MT municipality

\begin{tabular}{|c|c|c|c|c|c|}
\hline \multirow{2}{*}{ Categories } & \multirow{2}{*}{ Thematic classes } & \multicolumn{4}{|c|}{ Area } \\
\hline & & ha & $\%$ & ha & $\%$ \\
\hline \multirow{4}{*}{$\begin{array}{c}\text { Natural } \\
\text { Vegetation }\end{array}$} & $\begin{array}{l}\text { Seasonal Semi-deciduous sub-montane } \\
\text { Forest }\end{array}$ & 11531.55 & 7.21 & \multirow{4}{*}{51854} & \multirow{4}{*}{32.410} \\
\hline & Seasonal Semi-deciduous Alluvial Forest & 12539.60 & 7.84 & & \\
\hline & Savanna/ Seasonal Forest & 1671.08 & 1.04 & & \\
\hline & Forest Savanna + Park Savanna & 26112.00 & 16.32 & & \\
\hline \multirow{3}{*}{$\begin{array}{l}\text { Human } \\
\text { Use }\end{array}$} & Livestock + Secondary Vegetation & 49.04 & 0.03 & \multirow{3}{*}{108129} & \multirow{3}{*}{6.57} \\
\hline & Urban influence & 597.10 & 0.37 & & \\
\hline & Livestock & 10748321.22 & 67.17 & & \\
\hline Water bodies & Water & 40.52 & 0.03 & 40.52 & 0.03 \\
\hline Total area & & & & 160024 & 100 \\
\hline
\end{tabular}


Next, there are the characterizations of vegetation cover and land use according to BRASIL (2012, p.83).

The Semi-deciduous Alluvial Seasonal Forest is located inenvironments of sedimentary formations, characterized by the presence of large individuals, which stand out in their canopy, reaching 35 to $40 \mathrm{~m}$. They occur in the depressions of water courses, at altitudes around $200 \mathrm{~m}$, partially losing its leaves during the drought period. In the municipality, some fragments were mapped close to rivers and streams, since part of this vegetation was replaced for human use. The Sub-montane Semi-deciduous Forest occurs at altitudes varying between 300 and $450 \mathrm{~m}$, with variations of both structure and physiognomy, presenting, in some places exuberant structure with emergent canopy and height above $30 \mathrm{~m}$. In other sections they have fine structure, low size, uniform canopy. In Araputanga, it occurs at the highest altitudes, recorded in the central region of the municipality, corresponding to those areas with strong undulating, mountainous and steep relief, which according to the Forest Code (BRASIL, 2012, p.12) such natural vegetation must be preserved.

The Savanna areas occur in different climate types, but commonly in aluminized leached soils, presenting sinuses of small size hemi-criptophytes, geophytes, oligotrophic phanerophytes. In the northern section of the municipality, these sinuses were found covering sandy soils with low agriculture aptness. This fact is probably contributing to avoid its suppression.

Livestock consists in a set of primary activities, directly associated to agriculture and animal breeding. Livestock, which occupies over $67 \%$ of the municipal area, is the main municipal and regional economic source. Thus, it is necessary to establish or enlarge conservationist practices in order to get sustainability and keep the natural components with the increase of productivity in those areas already in use, in parallel with the reduction of new pasture areas, favoring the conservation of remnants of the natural vegetation from the municipality.

The Urban Influence class corresponds to built-up areas for residential, commercial and industrial use. Water Bodies correspond to lakes and reservoirs, which occur in both urban and rural areas.

Eight compartments were identified in Araputanga city (Table 3 and Figure 4). Compartment 5 had a larger area, formed by Luvissolos + System of Folded Bands $(32.70 \%)$, followed by compartment 4 , composed by Luvissolos + Desiccation System in Hills and Hills (29.50\%).

\section{Table 3 - Description and representativeness of the geomorphologic- pedologic compartments in the Araputanga municipality}

\begin{tabular}{clrr}
\hline Comp. & \multicolumn{1}{c}{ Geomorphology-Pedology } & Area (ha) & (\%) \\
\hline 1 & Red-Yellow Acrisols + Meander floodplain & 13553.05 & 8.47 \\
2 & Red-Yellow Acrisols + Floodplain system & 1510.05 & 0.95 \\
3 & Red Oxisol + Pediment system & 11313.32 & 7.07 \\
4 & Luvisols + Dissection system in hills & 47201.59 & 29.50 \\
5 & Luvisols + System of folded bands & 52316.17 & 32.70 \\
6 & Luvisols + Systems of plateaus with horizontal strata & 2327.46 & 1.45 \\
7 & Quartzarenic Arenosols + Meander floodplain & 31640.44 & 19.78 \\
8 & Histosols + Meander floodplain & 140.15 & 0.08 \\
\hline Total & & $\mathbf{1 8 7 9 . 8 3 8 . 0 7}$ & $\mathbf{1 0 0}$ \\
\hline
\end{tabular}


The Luvisols occur in $62.93 \%$ of the municipality area, corresponding to the most representative class (Figure 5 ). These soils vary from well to imperfectly drained, being usually shallow (60 to $120 \mathrm{~cm}$ ), with horizons A, Bt and C, and distinct differentiation between horizons $\mathrm{A}$ and $\mathrm{Bt}$, due to texture, color and / or structure contrast among them (EMBRAPA, 2006, p.24).

The Quartzarenic Arenosols, which occupy $19.77 \%$ of the municipality, are characterized by the absence of lithic contact in the first $50 \mathrm{~cm}$ depth, have a sequence of "AC" horizonsthat usually present aluminum toxicity. The sandy texture in all horizons can be constituted by $95 \%$ quartz, which conditions a low retention of moisture and of possible nutrient elements applied, being characterized as strong limitations to agricultural utilization (EMBRAPA, 2006, p.21; COELHO et al., 2002, p.111).
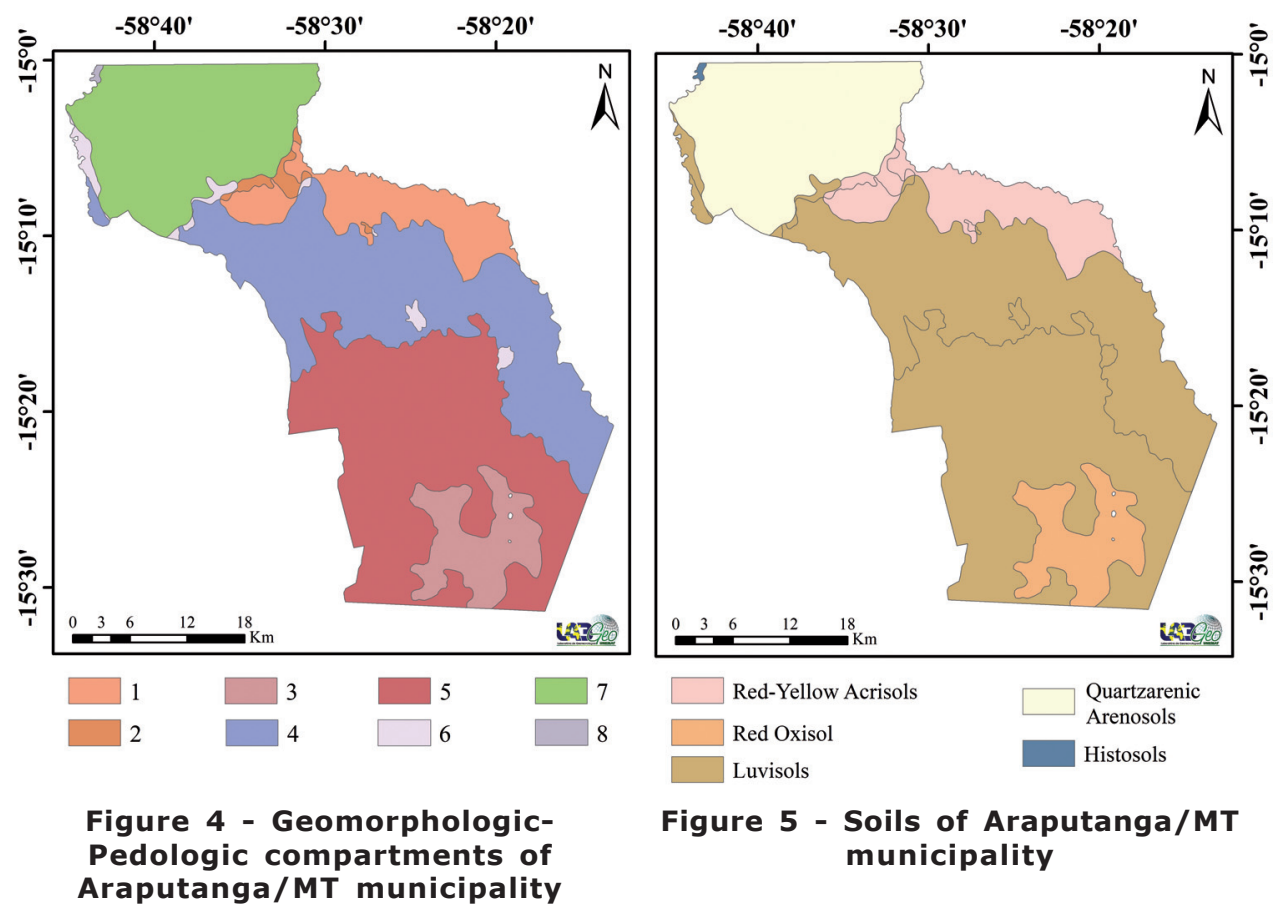
Figure 5 - Soils of Araputanga/MT municipality

The predominant relief class in the municipality is light undulated, occurring in $50 \%$ of the area, followed by plain relief with $28 \%$, and undulated, with $19 \%$ (Figure $6)$. According to Silva et al. (1999, p.111), the use of light and undulated areas requires the adoption of simple soil conservation practices, such as: soil tillage and contour planting, use of permanent contour vegetation, crop rotation and Incorporation of cultural remains into the soil.

Regarding erodibility, the most expressive class was High erodibility, present in compartments $1,2,4,5$, and 6 which correspond to $73.09 \%$ of the municipal area, with soils units Red-Yellow Acrisols and Luvisols (Figure 7). Acrisols are normally very erodible soils, mainly due to its intrinsic physical conditions, such as the texture gradient, i.e. the texture difference among surface and sub-surface horizons (BRASIL, 2007b, p.32). Luvisols present physical characteristics similar to Acrisols with some problems: 
little depth and normally high amount of gravel, problems associated to low permeability on the top of horizon B, resulting in a high erodibility (LEPSCH, 2011, p.33).

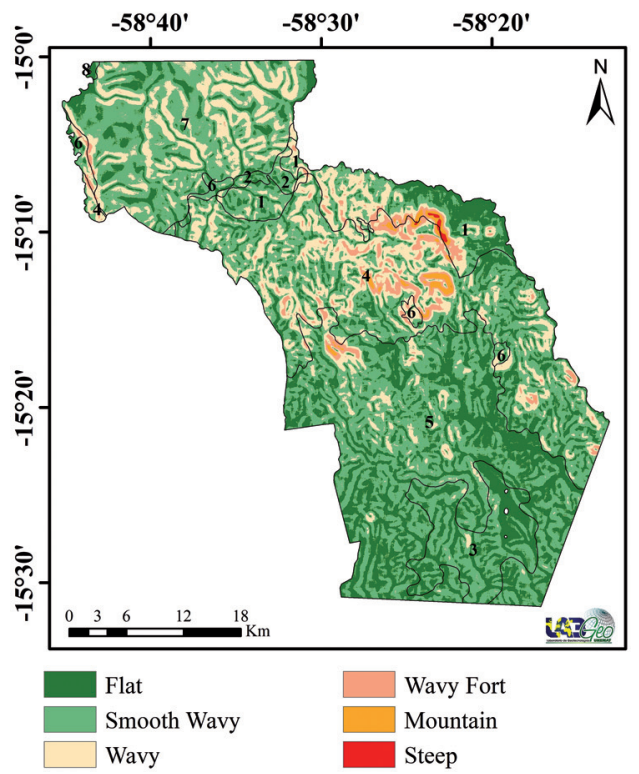

Figure 6 - Declivity in Araputanga/ MT municipality

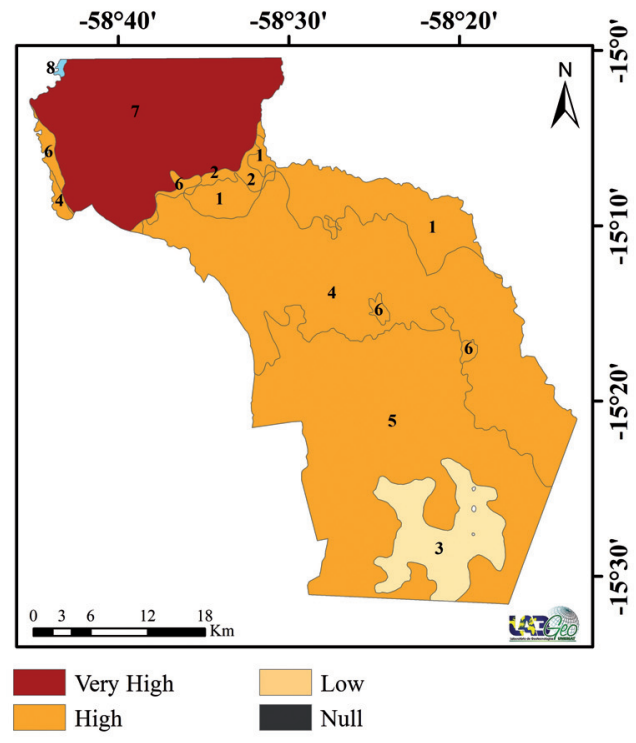

Figure 7 - Soils erodibility classes in Araputanga/MT municipality

The second most expressive erodibility was very high, with $19.80 \%$, occurring only in compartment 7, on Quartzarenic Arenosols. According to Neves et al. (2011, p.431) these soils are sandy and quartz rich, without weathered primary minerals, presenting low retention of nutrients and water. Due to the low adhesion and cohesion among particles, they have a high erodibility and are susceptible to high soil losses. This characteristic requires the adoption of conservationist practices, aiming to improve the soil structure and the reduction of degradation by erosion (VALLE JUNIOR et al., 2008, p.30).

The area with predominance of Red Oxisols, found in compartment 3, presented a low level of erodibility $(7.07 \%)$, verified at Figure 5 , justified by the junction of factors inherent to soil and relief, with declivity values below $3 \%$. Considering that these soils are deep, well drained, with low exchange capacity, medium to fine texture (clayey to very clayey), they present good aggregate stability. Therefore, these soils are more stable and indicative of a higher structural quality (EMBRAPA, 2006, p.265; DE SOUZA et al., 2015, p.10).

Compartment 8 , represented by Histosols in the floodplain region, was classified as with nil erodibility, corresponding to $0.08 \%$ of the municipal area.

The largest part of the municipal area is classified as very susceptible to water erosion $(73.16 \%)$ as a consequence of high erodibility soils and of their use for livestock activity (Figure 8). 

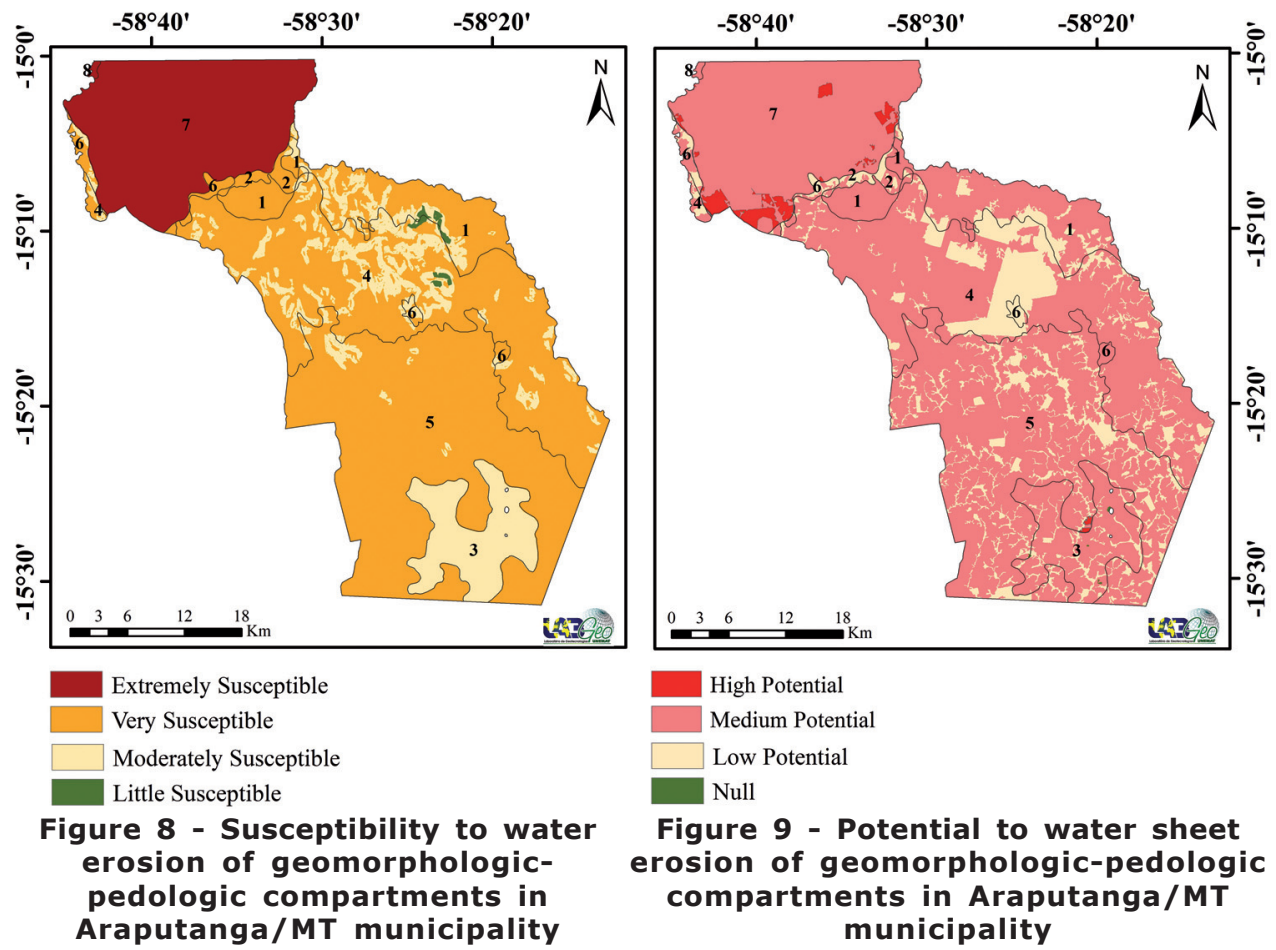

Figure 9 - Potential to water sheet erosion of geomorphologic-pedologic compartments in Araputanga/MT municipality

However, the geomorphologic compartment 7 was the only one classified as extremely susceptible to water erosion (Figure 8 ), possibly due to the soil type (Quartzarenic Arenosols), of high erodibility and to the light rolling to rolling relief. According to COGO (2003, p.479), the relief is a factor which strongly influences soil losses due to water erosion because with the increase of declivity there is an increase of the transport capacity of particles, reducing the water infiltration in the soil. Besides reducing its production capacity for cultures, erosion can cause considerable environmental damage, such as silting and pollution of the water sources. In spite of that, using adequate soil management systems and conservationist practices as support, the erosion problems can be satisfactorily solved.

Regarding the potential of water erosion, which indicates the intensity of human activities in areas susceptible to erosion, it was found out that $82.90 \%$ of the municipal area presents a medium potential, partially occurring in all compartments (Figure 9). This is justified by the present land use which is incompatible with the susceptibility to sheet erosion. However, it was observed that from this percentage, $22.09 \%$ refers to compartment 7, is composed by Quartzarenic Arenosols, which are highly susceptible to erosion, but it is in equilibrium because it is covered by natural vegetation. Therefore, it is recommended to keep the vegetation to protect the soil and the water springs, considering that there are several sources in this area. It is emphasized that the major problems regarding erosion in Quartzarenic Arenosols occur when these soils are unprotected by a vegetation cover, aggravating the shortage situation of aggregating materials (clay and organic material), which would increase the sediment load resulting from these processes in the water bodies and causing silting (PASSOS, 2010, p.29). 
The other areas with Acrisols, Oxisols and Luvisols need an adequate management with conservationist practices to establish the resilience of agro-livestock activities in consonance with environmental conservation.

It was verified that $1.54 \%$ of the area from the municipality, corresponds to the class of High potential erosion, which means that the current use of the soil is incompatible with its susceptibility to laminar erosion. This occurs in areas of compartment 7, where soils are fragile and natural cover has been withdrawn due to the expansion of livestock farming in the region, which can lead to environmental damage due to improper use. According to Pruski et al. (2006, p.165), when the occupation is carried out without observing the limits and risks of environmental degradation, it can cause the development of accelerated erosive processes, being one of the main factors causing degradation and deterioration of environmental quality.

From this municipal area, $15.52 \%$ is classified as with low erosion potential, and the current soil use is compatible with its susceptibility to laminar erosion. These sections are covered by natural vegetation (Alluvial Forest, Savanna and Semi Deciduous Seasonal Forest).

Those areas classified as nil potential to erosion $(0.02 \%)$ correspond to the places occupied by water (rivers, streams and lagoons).

From the total Araputanga land area, $58.37 \%$ presented a medium conflict of use due to the predominance of Luvisols and Acrisols in areas of flat to light rolling relief, originally occupied by low vegetation (Figure 10). According to Morgan (1996, p.08), the reduction of vegetation cover can increase the erosion by surface flow. This is because there will be more rain reaching the soil surface and less being intercepted by vegetation, which will entail the soil crumbling and reduce water infiltration. These areas are partially favorable to grazing and are more suitable for reforestation. In view of this, it is necessary to adopt preventive measures to avoid the degradation of the natural environments, as well as the appropriate land management according to its capacity of use.

Approximately $40.06 \%$ of the municipality presents a low conflict of use due to the presence of Oxisols and Histosols in flat relief and the presence of natural vegetation, being able to be cultivated only occasionally, since these areas are indicated for pastures and perennial crops. According to Ebeling et al., (2013, p.769) Histosols as well as Oxisols, are intensively used for family agriculture and are of great environmental importance due to its constitution, being formed by depositions of vegetal residues in different stages of decomposition resulting in high levels of organic matter and high natural fertility, which increases the agricultural potential of these soils (SILVA et al., 1999, p.114). 


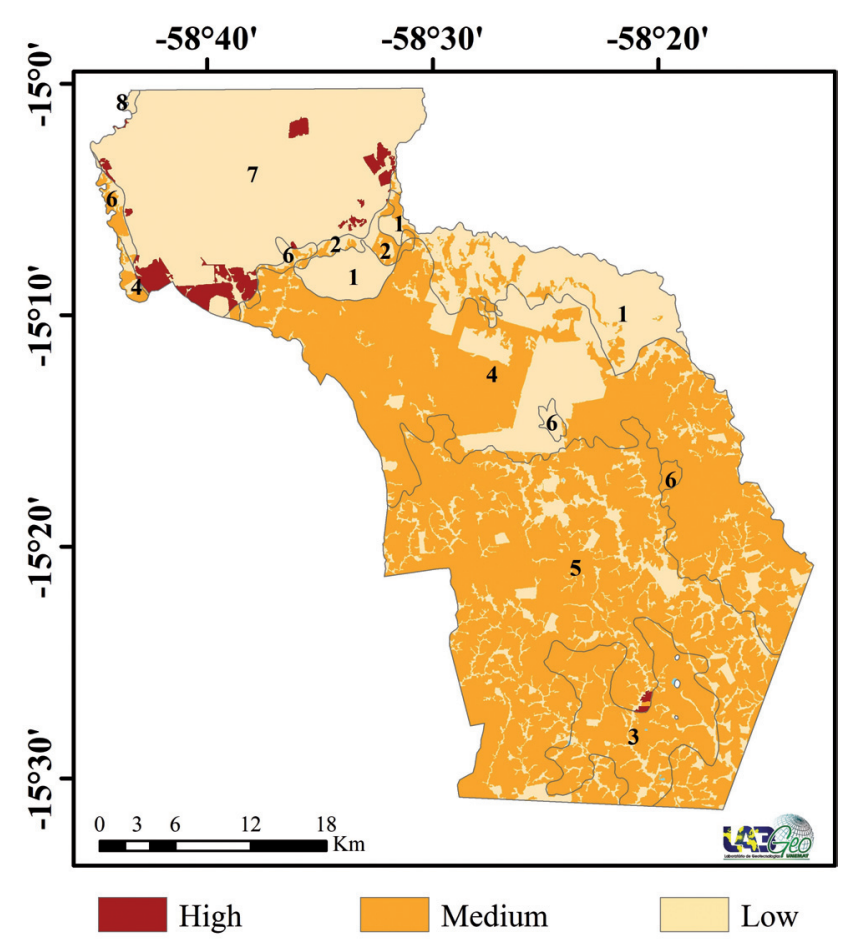

Figure 10 - Conflict of land use in the municipality of Araputanga / MT

In $1.53 \%$ of Araputanga's municipal area, the current land use is incompatible with the land use capacity, implying a high conflict. In these places the relief is light hilly to hilly and Arenosols predominate, which are considered fragile because of its sandy texture, conditioning low values of organic matter and CEC, as well as a high infiltration speed, making them highly erodible. Contrasting the effect of texture the position of these soils in the landscape, in flat to low relief, with slope below $3 \%$, make them less vulnerable to erosion (VALE JÚNIOR et al., 2008, p.75).

These results highlight the need to use intense conservation practices to prevent degradation processes. Custódio Filho (2011, p.76) proposes some measures for the stabilization of the erosive process in agricultural areas, namely: isolation of the affected area with fence, avoiding cattle access, avoidance of traffic from machines which form tracks and hinder the growth of vegetation, for example. 


\section{Table 4 - Characterization of geomorphologic-pedologic compartments and classification of land use conflicts in the municipality of Araputanga - MT}

\begin{tabular}{|c|c|c|c|c|c|c|}
\hline Compartmento & Vegetation cover and actual land use & Relief & ${ }^{1}$ Suscep.. & 2 Pot. & ${ }^{3}$ Cap. & ${ }^{4}$ Con. \\
\hline $\begin{array}{l}\text { 1. Acrissol Red- } \\
\text { Yellow + Meander } \\
\text { Floodplain }\end{array}$ & 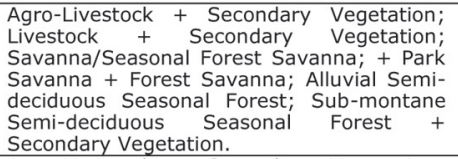 & $\begin{array}{l}\text { Light } \\
\text { Rolling } \\
\text { to Rolling }\end{array}$ & $\begin{array}{c}\text { Very } \\
\text { Susceptible }\end{array}$ & Medium & VI & Medium \\
\hline $\begin{array}{l}\text { 2. Acrissol Red- } \\
\text { Yellow }+ \\
\text { Floodplain System }\end{array}$ & $\begin{array}{l}\text { Agro-Livestock + Secondary Vegetation; } \\
\text { Savanna arborizada + Savana Parque + } \\
\text { Forest Savanna; Alluvial Semi-deciduous } \\
\text { Seasonal Forest, Sub-montane Semi- } \\
\text { deciduous Seasonal Forest + Secondary } \\
\text { Forest; Livestock + Secondary Forest. }\end{array}$ & $\begin{array}{l}\text { Light } \\
\text { Rolling } \\
\text { to } \\
\text { Rolling }\end{array}$ & $\begin{array}{c}\text { Very } \\
\text { Susceptible }\end{array}$ & $\begin{array}{l}\text { Low to } \\
\text { Medium }\end{array}$ & VI & Medium \\
\hline $\begin{array}{l}\text { 3. Oxisol Red }+ \\
\text { Pediment System }\end{array}$ & $\begin{array}{l}\text { Agro-Livestock + Secondary Vegetation; } \\
\text { Alluvial Semi-deciduous Seasonal Forest; } \\
\text { Sub-montane Semi-deciduous Seasonal } \\
\text { Forest + Secondary Vegetation; Livestock } \\
+ \text { Secondary Vegetation; Water mass; } \\
\text { Urban Influence. }\end{array}$ & $\begin{array}{l}\text { Flat to } \\
\text { Light } \\
\text { Rolling }\end{array}$ & $\begin{array}{l}\text { Moderately to } \\
\text { Little Susceptible }\end{array}$ & Medium & IV & Low \\
\hline $\begin{array}{l}\text { 4. Luvisols + } \\
\text { Dissection system } \\
\text { in hills }\end{array}$ & $\begin{array}{l}\text { Agro-Livestock + Secondary Forest; } \\
\text { Savanna/ Seasonal Forest; Savanna Forest } \\
+ \text { Park Savanna + Savanna Forest; Alluvial } \\
\text { Semi-deciduous Seasonal Forest; Sub- } \\
\text { montane Semi-deciduous Seasonal Forest } \\
+ \text { Secondary Vegetation; Livestock + } \\
\text { Secondary Vegetation. }\end{array}$ & $\begin{array}{l}\text { Light } \\
\text { Rolling to } \\
\text { Rolling }\end{array}$ & Very Susceptible & $\begin{array}{l}\text { Low to } \\
\text { Medium }\end{array}$ & VI & Medium \\
\hline $\begin{array}{l}\text { 5. Luvisols }+ \\
\text { System of folded } \\
\text { bands }\end{array}$ & $\begin{array}{l}\text { Agro-Livestock + Secondary Vegetation; } \\
\text { Sub-montane Semi-deciduous Seasonal } \\
\text { Forest + Secondary Forest; Livestock + } \\
\text { Secondary Forest; Water mass; Urban } \\
\text { influence; Alluvial Semi-deciduous Seasonal } \\
\text { Forest; Livestock + Secondary Vegetation. }\end{array}$ & $\begin{array}{l}\text { Flat to } \\
\text { Light } \\
\text { Rolling }\end{array}$ & $\begin{array}{l}\text { Moderately } \\
\text { Susceptible. }\end{array}$ & Medium & IV & Low \\
\hline $\begin{array}{l}\text { 6. Luvisols }+ \\
\text { Systems of } \\
\text { plateaus with } \\
\text { horizontal strata }\end{array}$ & $\begin{array}{l}\text { Agro-Livestock + Secondary Vegetation; } \\
\text { Forest Savanna + Park Savanna + Forest } \\
\text { Savanna; Alluvial Semi-Deciduous Seasonal } \\
\text { Forest; Livestock + Secondary Vegetation; } \\
\text { Urban Influence; Sub-montane Semi- } \\
\text { deciduous Seasonal Forest + Secondary } \\
\text { Vegetation. }\end{array}$ & $\begin{array}{l}\text { Light } \\
\text { Rolling to } \\
\text { Rolling }\end{array}$ & $\begin{array}{l}\text { Moderately to } \\
\text { little susceptible }\end{array}$ & $\begin{array}{l}\text { Low to } \\
\text { Medium }\end{array}$ & IV & Medium \\
\hline $\begin{array}{l}\text { 7. Arenosols }+ \\
\text { Meander floodplain }\end{array}$ & $\begin{array}{l}\text { Agro-Livestock + Secondary Vegetation; } \\
\text { Forest Savanna + Park Savanna + Forest } \\
\text { Savanna; Alluvial Semi-deciduous Seasonal } \\
\text { Forest; Livestock + Secondary Vegetation; } \\
\text { Water mass; Livestock + Secondary } \\
\text { Vegetation }\end{array}$ & $\begin{array}{l}\text { Light } \\
\text { Rolling to } \\
\text { Rolling }\end{array}$ & $\begin{array}{l}\text { Extremely } \\
\text { Susceptible }\end{array}$ & $\begin{array}{l}\text { High } \\
\text { and } \\
\text { Medium }\end{array}$ & $\begin{array}{l}\text { VII e } \\
\text { VIII }\end{array}$ & High \\
\hline $\begin{array}{l}\text { 8. Histosols+ } \\
\text { Meander floodplain }\end{array}$ & $\begin{array}{l}\text { Forest Savanna + Park Savanna + Forest } \\
\text { Savanna }\end{array}$ & $\begin{array}{l}\text { Flat to } \\
\text { Light } \\
\text { Rolling }\end{array}$ & $\begin{array}{l}\text { Extremely } \\
\text { Susceptible }\end{array}$ & Medium & $\begin{array}{l}\text { VII e } \\
\text { VIII }\end{array}$ & Low \\
\hline
\end{tabular}

${ }^{1}$ Susceptibility to water erosion; 2 Potential to sheet water erosion; 3 Capacity of land use; ${ }^{4}$ Land use conflict.

The economy from the municipality under study is based on agriculture, evidenced by an increase of $93 \%$ in the number of heads between 2008 and 2012, and 1,650 ha occupied by soybean and corn (MATO GROSSO, 2012, p.194). The intensive use of several areas from the municipality without observing the respective limitations of those areas classified as extremely susceptible to erosion that were presented in this study, may compromise their productive capacity.

The maps presented in this research reflect the conditions related to the time at which land use and occupation data were obtained. They should be periodically updated to reflect the real risks of erosive processes, which are dynamic because they are subjected to climatic conditions and human action. 


\section{CONCLUSIONS}

The natural components of the landscape were explored without observing its limitations, which was evidenced by the results of the susceptibility to water erosion, the potential for laminar water erosion and land use capacity.

The soils in the Araputanga municipality present a high erodibility and are very susceptible to water erosion, due to their physical and chemical characteristics.

The agricultural activities in the municipality are growing, so it is recommended that soil conservation plans are defined in order to minimize the impacts of land use on the natural components of the landscape, such as soil and water.

\section{ACKNOWLEDGEMENTS}

We acknowledge CNPq (National Council for Research) for granting a technical assistant scholarship ñ level B and FAPEMAT (Mato Grosso State Foundation for Research) for a scientific initiation scholarship. To Prof. Dr. Ronaldo José Neves for his contributions and conduction of this study while he was present among us.

\section{REFERENCES}

ARAGÃO, R.; ALMEIdA, J. A. P.; FIGUEIREdo, E. E.; SRINIVASAN, V. S. Mapeamento do potencial de erosão laminar na Bacia do Rio Japaratuba, SE, via SIG. Revista Brasileira de Engenharia Agrícola e Ambiental, Campina Grande-PB, v. 15, n. 7, p. 731 - 740, 2011.

BRASIL. Ministério de Minas e Energia Secretaria de Geologia, Mineração e Transformação Mineral Serviço Geológico do Brasil. THOMÉ FILHO, J. J.; SCISLEWSKI, G.; SHINZATO, E.; ROCHA, G. A.; DANTAS, M.; CASTRO JR., R. P.; ARAÚJO, E. S.; MELO, D. C. R.; ARMESTO, R. C. G.; ARAÚJO, L. M. N. (Orgs). Sistema de Informação Geoambiental de Cuiabá, Várzea Grande e Entorno - SIG CUIABÁ. Goiânia: CPRM, 2006. 303p.

BRASIL. Instituto Brasileiro de Geografia e Estatística. Manual técnico de pedologia. 2 ed. Rio de Janeiro: IBGE, 2007b. 191p.

BRASIL. Instituto Brasileiro de Geografia e Estatística. Censo Demográfico - 2010. Rio de Janeiro: IBGE, 2010. Disponível em: http://www.cidades.ibge.gov.br/v3/cidades/ municipio/5101258. Acesso em: 03 jan. 2017.

BRASIL. Lei 12651/2012. Código Florestal Brasileiro [on line] http:// www.planalto.gov.br/ccivil03/leis/L4771.htm. Acesso dia 07/02/2017.

BRASIL. Lei $\mathbf{n}^{\circ} \mathbf{1 2 . 6 5 1}$, de 25 de maio de 2012. Institui Código Florestal Brasileiro. Disponível em: http://www.planalto.gov.br/ccivil_03/_ato2011-2014/2012/lei/ I12651.htm. Acesso em: 31 mar 2017.

BRASIL. Projeto de Conservação e Utilização Sustentável da Diversidade Biológica Brasileira. Levantamento da cobertura vegetal nativa do bioma Cerrado: estratégias e resultados. Rio de Janeiro: Probio, 2007a. 33p. 
BRASIL. Instituto Brasileiro de Geografia e Estatística. Censo Demográfico - 2010. Rio de Janeiro: IBGE, 2012. Disponível em: <http://www.ibge.gov.br/cidadesat/ topwindow.htm?1.>. Acesso em: 19 jun. 2017.

BRASIL. Instituto Brasileiro de Geografia e Estatística. Manual Técnico da Vegetação Brasileira. 2 ed. Rio de Janeiro: Diretoria de Geociências, 2012. 271p.

CÂMARA, G.; SOUZA, R. C. M.; FREITAS, U. M.; GARRIDO, J. SPRING: Integrating remote sensing and GIS by object-oriented data modeling. Computers \& Graphics, Dordrecht-Holanda, v. 20, n. 3, p. 395 - 403, 1996.

CARVAlHo, N. O. Hidrossedimentologia Prática. 2 ed. Rio de Janeiro: Interciência, 2008. 600p.

COELHO, M. R.; SANTOS, H. G.; SILVA, E. F.; AGLIO, M. L. D. O Recurso Natural do Solo. In: MANZATTO, C. V. (Org.). Uso Agrícola dos Solos Brasileiros. Rio de Janeiro: Embrapa Solos, 2002. p. 1-12.

COGO, N. P.; LEVIEN, R.; SCHWARZ, R. A. Perdas de solo e água por erosão hídrica influenciadas por métodos de preparo, classes de declive e níveis de fertilidade do solo. R. Bras. Ci. Solo, Viçosa-MG, v. 27, n. 4, p.743-753, 2003.

CUSTÓDIO FILHO, R. O. Recuperação e monitoramento de voçoroca em Neossolo Quartzarênico no município de Baliza, GO. 2011. 98 f. Dissertação (Mestrado em Agronomia) - Universidade Federal de Goiás, Escola de Agronomia, Baliza-GO, 2011.

DE SOUZA, L. H. C.; NUNES, C. M. N.; NEVES, S. M. A. S. CUIABANO, M. N.; FERREIRA, S.F.; SOUZA, A. L. Estabilidade de agregados de um latossolo vermelho distrófico sob diferentes usos e manejos em Lambari D'Oeste-MT. Revista do Centro Universitário de Patos de Minas, Patos de Minas, v. 6, n. 1. p. 12-23, 2015.

Ebeling, A. G.; ANJOS, L. H. C.; PEREZ, D. V.; PEREIRA, M. G.; NOVOTNY, E. H. Atributos físicos e matéria orgânica de Organossolos Háplicos em distintos ambientes no Brasil. Revista Bras. Cienc. Solo, Viçosa, v. 37, n 3. p. 763-774, 2013.

EMBRAPA. C. N. P.S. Sistema Brasileiro de Classificação de Solos. 2 ed. Rio de Janeiro: Embrapa-CNPS, 2006. 306p.

ESRI. ArcGis advanced: realease 10.5. Redlands, CA: Environmental Systems Research Institute, 2017.

FORNELOS, L. F.; NEVES, S. M. A. S. Uso de modelos digitais de elevação (MDE) gerados a partir de imagens de radar interferométricos (SRTM) na estimativa de perdas de solo. Revista Brasileira de cartografia, Rio de Janeiro, v. 59, n. 3, p. 25-33, 2007.

FROTA, P. V.; NAPPO, M. E. Processos erosivos e a retirada da vegetação na bacia hidrográfica do Açude Orós - CE. Revista Geonorte, v. 4, n. 4, p. 1472-1481, 2012. HERMUCHE, P. M.; GUimARÃES, G. M. A.; CASTRO, S. S. Análise dos compartimentos morfopedológicos como subsídio ao planejamento do uso do solo em Jataí - GO. GEOUSP - Espaço e Tempo, São Paulo, v. 1, n. 26, p. 113 - 131, 2009.

INBAR, M.; TAMIR, M.; WITTENBERG, L. Runoff and erosion process after a forest fire in Mount Carmel, a Mediterranean area. Geomorphology, Amsterdam, v. 24, n. 1, p. 17-33, 1998.

LEPSCH, I. (Org.). Manual para o levantamento do meio físico de classificação das terras no sistema de capacidade de uso. 2 ed. Campinas/SP: Soc. Bras.de Ciência do Solo, 1991. 175p.

LEPSCH, I. F. 19 lições de pedologia. São Paulo: Oficina de Textos, 2011. 45p. 
LIMA, F. R.; MARTINELLI, M. As unidades ecodinâmicas na Cartografia Ambiental de Síntese. In: SIMPÓSIO DE PÓS-GRADUAÇÃO EM GEOGRAFIA DO ESTADO DE SÃO PAULO, 1., Rio Claro-SP, 2008. Anais... Rio Claro-SP: UNESP, 2008. p. 1333-1345.

MAFRA, N. M. C. Esquema metodológico para la planificación de usos del suelo em zonas tropicales húme-das: aplicación a la region Norte del Estado del Rio de Janeiro, Brasil. 1997. 229 f. Tese (Doutorado em Edafologia) - Facultad de Geografía e História, Universidade de Valencia, Valencia, 1997.

MATO GROSSO. Secretaria de Estado de Planejamento e Coordenação Geral. MOREIRA, M. L. C.; VASCONCELOS, T. N. N. (Org.). Mato Grosso: solos e paisagem. Cuiabá: SEPLAN/MT, 2007. 272p.

MATO GROSSO. Secretaria de Estado de Planejamento e Coordenação Geral. Plano de Longo Prazo de Mato Grosso: macro-objetivos, metas globais, eixos estratégicos e linhas estruturantes, 2012. In: PRADO, J. G. B.; BERTCHIELI, R.; OLIVEIRA, L. G. (Org.). Plano de Longo Prazo de Mato Grosso. Cuiabá/MT: Central de Texto, 2012. p. 63-74.

MORGAN, G. Imagens da organização. São Paulo: Atlas, 1996. 11p.

NASCIMENTO, P. S. R.; GETULIO, T. B.; RAIMUNDO, A. F. Efeito de Pré-Processamento (ajuste) no Desempenho da Segmentação e Classificação De Imagens Landsat-TM. In: SIMPÓSIO BRASILEIRO DE SENSORIAMENTO REMOTO, 9., Santos-SP, 1998. Anais... São José dos Campos: INPE, 1998. p. 981-989.

NEVES, S. M. A. S.; NUNES, C. M. N.; NEVES, R. J.; SOARES, E. R. C. Estimativa da perda de solo por erosão hídrica na bacia hidrográfica do rio Jauru/MT. Soc. nat. Uberlândia-MG, v. 23, n. 3, p. 423-433, 2011.

OLIVEIRA, J. R.; PINTO, M. F.; SOUZA W. J.; GUERRA, J. G. M.; CARVALHO D. F. Erosão hídrica em um Argissolo Vermelho-Amarelo, sob diferentes padrões de chuva simulada. Rev. bras. eng. agríc. ambient., Campina Grande-PB, v. 14, n. 2, p. 140-147, 2010.

PASSOS, P. F. Uso de técnicas de geoprocessamento para estimativa de áreas susceptíveis à erosão na bacia hidrográfica do rio Mamanguape-PB. In: SIMPÓSIO BRASILEIRO DE CIÊNCIAS GEODÉSICAS E TECNOLOGIAS DA GEOINFORMAÇÃO, 3., Recife-PE, 2010. Anais... Recife-PE: UFPE, 2010. p. 27-30.

PRUSKI, F. F.; AMORIM, R. S. S.; SILVA, D. D.; GRIEBELER, N. P.; SILVA, J. M. A. Conservação de solo e água: praticas mecânicas para o controle da erosão hídrica. Viçosa-MG: Universidade Federal de Viçosa, 2006. 240p.

ROSS, J. L. S. Geomorfologia: ambiente e planejamento. São Paulo: Contexto, 1990. 85p.

SALOMÃO, F. X. T. Controle e prevenção dos processos erosivos. In: GUERRA, A. J. T.; SILVA, A. S. S.; BOTELHO, R.G. M. (Org.). Erosão e conservação dos solos: conceitos, temas e aplicações. Rio de Janeiro: Bertrand Brasil, 2010. p. 229-267.

SILVA, A. B.; BRITES, R. S.; SOUSA, A. R. Caracterização do meio físico da microbacia Quatro Bocas, em Angelim, PE e sua quantificação por Sistema de Informação Geográfica. Pesq. agropec. bras., Brasília, v. 34, n.1, p.109 -117, 1999.

TARIFA, J. R. Mato Grosso: clima - Análise e representação cartográfica. Cuiabá: Entrelinhas, 2011. 101p.

VALLE JUNIOR, R. F. Diagnóstico de áreas de risco de erosão e conflito de uso dos solos na bacia do rio Uberaba. 2008. 222 f. Tese (Doutorado em Agronomia) - Faculdade de Ciências Agrárias e Veterinárias. Universidade Estadual Paulista, Jaboticabal-SP, 2008. 